\title{
The influence of entrepreneurship competence to entrepreneurships orientation on beef cattle farmer in Karanganyar regency
}

\author{
Sutrisno Hadi Purnomo ${ }^{1 *}$, Eka Handayanta ${ }^{1}$, Agni Hanifa ${ }^{1}$, Ayu Intan Sari $^{1}$, Shanti Emawati ${ }^{1}$, \\ and Endang Tri Rahayu ${ }^{1}$ \\ ${ }^{1}$ Dept. of Animal Science, Faculty of Agriculture, Universitas Sebelas Maret, Jl Ir Sutami 36A \\ Surakarta 57126, Indonesia.
}

\begin{abstract}
This research aims to analyze the influence and relationship of entrepreneurial competence to entrepreneurship orientation of beef cattle business. The research was conducted in Tasikmadu, Karanganyar, Central Java Indonesia at February-April 2021. Methods of data collection using survey method with questionnaire as primary data retrieval tool. The method of determining the respondents using census method on all farmers who attended the training with the number of respondents 42 people. Method of determining the location by purposive sampling. Data analysis used was test of validity and reliability, multiple linear regression analysis continued test of determination $\left(\mathrm{R}^{2}\right), \mathrm{F}$ test, $\mathrm{t}$ test and classical assumption test. Validity test results show valid results $\mathrm{r}_{\text {hitung }}>\mathrm{r}_{\text {tabel }}$ is 0.304 and reliability value $\alpha>$ 0.6 on all variables. Multiple linear regression analysis obtained value of equation $\mathrm{Y}=0.741+0.350 \mathrm{X}_{1}+0.246 \mathrm{X}_{2}+0.264 \mathrm{X}_{3}+0.047 \mathrm{X}_{4}+0.011 \mathrm{X}_{5}+$ $0.038 \mathrm{X}_{6}$. The value of determination coefficient $\left(\mathrm{R}^{2}\right)$ is 0.608 , which means that entrepreneurship competence variable can explain the entrepreneurship orientation variable equal to $60.8 \%$. The entrepreneurial competence variable affects together toward the orientation with the value $F_{\text {count }}>F_{\text {table. }}$. It can be concluded that entrepreneurial competence consisting of communication, problem solving, initiative, planning and organization, selfawareness and technology simultaneous influence to entrepreneurial orientation.
\end{abstract}

\section{Introduction}

Indonesia as an agricultural country has a lot of potential resources that can be used as a business. One of the businesses that can be developed in Indonesia is beef cattle farming. The beef cattle business in Indonesia is still promising in line with the high demand for beef and the government's program to limit beef imports [1]. Livestock business, especially beef cattle farming in Indonesia is still promising because the market opportunities are quite open [2]. The livestock sector is a business sector that plays a very large role in meeting the needs of animal protein and various industrial needs. Beef cattle farming is one part of the agricultural

* Corresponding author: sutrisnohadi@staff.uns.ac.id 
sector that needs to be developed and utilized optimally, so it is necessary to continue to strive for its development in order to make a real contribution to the Indonesian economy [3]. In order to realize the fulfillment of beef needs in Indonesia, it is necessary to increase the entrepreneurial spirit of beef cattle farmers.

Entrepreneurship can be interpreted as a spirit, attitude and behavior as an example in the courage to take calculated risks based on one's own will and ability. According to [4], an entrepreneur is an individual who has the character to achieve higher than most other individuals. An entrepreneur must have entrepreneurial competence because with the entrepreneurial competence in himself entrepreneurs are expected to be able to build businesses and achieve business success [5]. Competence is the attitude, knowledge, skills and abilities needed by farmers to maximize their business performance. Farmers who have high competence will affect their entrepreneurial orientation. Entrepreneurial orientation is the tendency of farmers to innovate, be proactive and dare to take risks in managing their business [6].

Tasikmadu District is one of the areas in Karanganyar Regency which has a fairly high beef cattle population of around 5678 heads [7]. Beef cattle are cattle that are kept with the main purpose of producing meat. Most of the smallholder beef cattle business is a hereditary business with a maintenance pattern according to the ability of the breeder [8]. The development of beef cattle farming which is still in the traditional or traditional farming pattern results in a lack of entrepreneurial competence in the community [6]. Low business competence means lack of orientation so that business performance will not be optimal [9]. Therefore, it is necessary to conduct research to analyze the effect of entrepreneurial competence on the entrepreneurial orientation of beef cattle.

\section{Materials and methods}

This research was conducted using a survey method in Tasikmadu District, Karanganyar Regency on February - April 2021. The location of the research was determined by purposive sampling, located in Tasikmadu District, Karanganyar Regency. This is because the location is one of the centers of beef cattle business which has a large area of land and the availability of abundant feed so that the location is very supportive when used for data collection of beef cattle entrepreneur research. Sampling method using purposive sampling method, namely the technique of determining the sample with certain considerations [10]. The sample used as a respondent is a farmer who has at least 2 beef cattle in the District of Tasikmadu, Karanganyar Regency, members of the Subur Lestari Livestock Farmer Group who participated in the training with a total of 42 peoples.

The data analysis used in this research is quantitative data analysis using SPSS 22 software for windows. This study uses variables dépendent of entrepreneurial orientation and 6 independent variables, namely communication, problem solving, initiative, planning and organization, self-awareness and technology. The analysis of this research includes validity analysis to measure the validity of a question or questionnaire, if ( $r$-count $>r$-table) then the question item is valid [11], reliability analysis to measure a questionnaire which is an indicator of the variable, if the value cronbach's alpha $>0.6$ data is considered reliable [12].

Multiple linear regression analysis was used to determine the effect of the variables of communication, problem solving, initiative, planning and organization, self-awareness and technology on entrepreneurial orientation. Statistical test with coefficient of determination $\left(\mathrm{R}^{2}\right)$ to measure how far the ability of a model to explain the variation of the dependent variable, $\mathrm{F}$ test to find out the independent variables jointly affect the dependent variable at a significance level of 5\% (0.05), t test to test the variable partially independent effect on the dependent variable, $\mathrm{t}$-count $>\mathrm{t}$-table then Ho is rejected and $\mathrm{Ha}$ is accepted which means 
significant, t-count $<\mathrm{t}$-table then Ho is accepted which means it is not significant. Classical assumption test of residual normality to test the residual value of the regression model normally distributed or not, multicollinearity to see whether there is a correlation between independent variables, heteroscedasticity to determine whether there is a variance inequality from residual to other observations [12].

\section{Results and discussion}

Tasikmadu is one of the sub-districts in Karanganyar Regency which is located between $7^{0} 30^{\prime}-7^{0} 45^{\prime}$ South Latitude and $110^{\circ}-110^{\circ} 45^{\prime}$ East Longitude, which consists of 13 villages with an area of 5.508.43 Ha. The total population of Tasikmadu Subdistrict in 2020 was recorded at 62.501 people, consisting of 30.588 male residents and 31.913 female residents, with a population density of 1.135 people $/ \mathrm{km}$. The number of households is 18.196 and the average per household is 3-4 people.

Tasikmadu District has a total land area of 5.508.43 Ha of which $2.479 .83 \mathrm{Ha}$ is agricultural land. Tasikmadu District is a fertile area with abundant water availability so it has the potential to be used as agricultural land. Extensive land in the form of rice fields produces agricultural waste that can be used as animal feed. This makes it easier for farmers to find animal feed and reduces the costs incurred in the beef cattle business. The main livelihood of the people of Tasikmadu District is as farmers and has a side job, namely raising livestock, both ruminants and poultry. The type of ruminant livestock that is mostly kept is beef cattle of 7.552 heads [7].

\subsection{Characteristics of respondents}

Characteristics of respondents analysed in this study include gender, age, education level, occupation, length of raising and number of cattle ownerships. The characteristics of the respondents of entrepreneurship training participants can be seen in Table 1 .

Based on Table 1, the results of the study show that most of the respondents have an age ranging from 25 to 65 years, this means that most of the respondents are of productive age. According to [1] that the productive age group is 15 to 64 years old and the unproductive age group is more than 64 years old. The most recent education taken by respondents was at the high school level as many as 24 people or $57.14 \%$ which indicates that awareness of public education is quite high.

The main occupations of the respondents are farmers, as many as 19 respondents or $45.24 \%$, while 9 people or $21.43 \%$ have their main job as livestock entrepreneurs. This is because livestock entrepreneurs are mostly only used as side jobs. According to [3] that to deal with business risks such as production failure, farmers do side business as a source of income to meet the needs of their families. The majority of respondents had less than 5 livestock, which was $73.81 \%$ or 31 of the total number of respondents. This is in accordance with the opinion of [13], the scale of smallholder beef cattle farming is described by the small number of livestock ownership. This means that only 2-3 cattle owned by a farmer.

\subsection{Research instrument test}

The validity test criteria if the value of rcount $>$ rtable, then the statement item is said to be valid (Abdulrahman et al., 2011). The validity test of each item shows the value of rcount $>$ 0.304 (r-count $>$ r-table) it can be concluded that the statement item is valid. Cronbach's alpha 
value of all variables has the lowest value of 0.711 and the highest value of 0.872 so that all variables are said to be reliable. This is in accordance with the opinion of [14] if $(\alpha>0.6)$ then the statement item is reliable.

Table 1. Characteristics of respondents

\begin{tabular}{|c|c|c|}
\hline Characteristics & Number of people) & Percentage (\%) \\
\hline \multicolumn{3}{|l|}{ Age } \\
\hline $25-35$ & 9 & 21.4 \\
\hline $36-45$ & 9 & 21.4 \\
\hline $46-55$ & 9 & 21.4 \\
\hline $56-65$ & 13 & 31 \\
\hline$>65$ & 3 & 4.8 \\
\hline \multicolumn{3}{|l|}{ Education } \\
\hline Elementary school & 4 & 9.53 \\
\hline Junior high school & 5 & 11.9 \\
\hline Senior High School & 24 & 57.14 \\
\hline $\mathrm{S} 1 / \mathrm{D} 3$ & 9 & 21.43 \\
\hline \multicolumn{3}{|l|}{ Long time raising } \\
\hline$<5$ & 21 & 50 \\
\hline $5-10$ & 14 & 33.3 \\
\hline$>10$ & 7 & 16.7 \\
\hline \multicolumn{3}{|l|}{ Number of cattle ownerships } \\
\hline$<5$ & 31 & 73.81 \\
\hline $5-10$ & 8 & 19.05 \\
\hline$>10$ & 3 & 7.14 \\
\hline
\end{tabular}

Source: Processed Primary Data, 2021

\subsection{Analysis of factors affecting entrepreneurial orientation}

Factors that influence entrepreneurial orientation can be measured by multiple linear regression tests. The results of multiple linear regression can be seen in Table 2 .

Based on Table 2, the following multiple linear regression equation is obtained:

$\mathrm{Y}=0.741+0.350 \mathrm{X}_{1}+0.246 \mathrm{X}_{2}+0.264 \mathrm{X}_{3}+0.047 \mathrm{X}_{4}+0.011 \mathrm{X}_{5}+0.038 \mathrm{X}_{6}+\mathrm{e}$

The results of the multiple linear regression test in this study obtained a constant value $(\alpha)$ of 0.741 with a positive constant value. This means that if the independent variable is constant, the Entrepreneurial Orientation $(\mathrm{Y})$ of fattening beef cattle will increase by 0.741 [9]. The coefficient value for the Communication variable (X1) obtained a value of 0.350 and is positive. This means that communication has a positive influence on the entrepreneurial orientation and if the perception of communication increases by 1 unit, while other variables 
are considered constant, then there is an effect on increasing the value of the entrepreneurial orientation of beef cattle fattening by 0.350 .

Table 2. Multiple linear regression test results

\begin{tabular}{|l|c|c|c|c|}
\hline \multicolumn{1}{|c|}{ Variable } & $\begin{array}{c}\text { Regression } \\
\text { Coefficient }\end{array}$ & t-count & $\begin{array}{c}\text { t- } \\
\text { table }\end{array}$ & Sig.t (<0.05) \\
\hline X1 (Communication) & 0.350 & 1.526 & 2,030 & 0.136 \\
X2 (Troubleshooting) & 0.246 & 1.071 & 2,030 & 0.292 \\
X3 (Initiative) & 0.264 & 1.458 & 2,030 & 0.154 \\
X4 (Planning and organization) & 0.047 & 0.195 & 2,030 & 0.847 \\
X5 (Self-awareness) & 0.011 & 0.073 & 2,030 & 0.942 \\
X6 (Technology) & 0.038 & 0.224 & 2,030 & 0.824 \\
\hline Constant & 0.741 & & & 0.000 \\
\hline F count & 9,064 & & & \\
\hline R square (R ${ }^{2}$ ) & 0.608 & & \\
\hline Dependent variable $=$ Y (Entrepreneurship Orientation) & \\
\hline
\end{tabular}

Source: Processed Primary Data, 2021

The coefficient value for the Problem Solving variable (X2) obtained a value of 0.246 and is positive. This means that the Problem Solving variable has a positive influence on the Entrepreneurial Orientation and if the perception of problem solving increases by 1 unit, while other variables are considered constant, then there is an effect on increasing the value of the Entrepreneurial Orientation of beef cattle fattening by 0.246 . The coefficient value for the Initiative variable (X3) obtained a value of 0.264 and is positive. This means that the Initiative has a positive influence on the Entrepreneurial Orientation and if the perception of the Initiative increases by 1 unit, while other variables are considered constant, then there is an influence on the increase in the value of the Entrepreneurial Orientation of beef cattle fattening by 0.264 . The coefficient value for the Planning and Organization variable (X4) obtained a value of 0.047 and is positive. This means that Planning and Organization have a positive influence on Entrepreneurial Orientation and if the perception of Planning and Organization increases by 1 unit, while other variables are considered constant, then there is an effect on increasing the value of the Entrepreneurial Orientation of beef cattle fattening by 0.047 . The coefficient value for the Self-Awareness variable (X5) is obtained a value of 0.011 and is positive. This means that Self-Awareness has a positive influence on Entrepreneurial Orientation and if the perception of Self-Awareness increases by 1 unit, while other variables are considered constant, then there is an effect on the increase in the value of Entrepreneurial Orientation for beef cattle fattening by 0.011 . The coefficient value for the Technology variable (X6) is obtained a value of 0.036 and is positive. This means that the use of technology has a positive influence on the Entrepreneurial Orientation and if the perception of the use of technology increases by 1 unit, while other variables are 
considered constant, then there is an effect on the increase in the value of the Entrepreneurial Orientation of beef cattle fattening by 0.036 .

The coefficient of determination (R2) essentially measures how far the ability of a model to explain variations in the dependent variable. The value of determination is between zero and one [12]. Based on Table 2, the determination value is 0.608 . This shows that the independent variable contributes to the influence of the dependent variable by $60.8 \%$ and the rest is influenced by other variables not examined in this study.

According to [14] if F-count $<$ F-table then Ho is accepted and if F-count $>$ F-table then Ho is rejected. Based on Table 2, it can be seen that the F-count value is 9.064 and the F-table value can be seen based on the F statistic table with a 5\% significance level of 2.372 . The data shows the value of F-count $>$ F-table which is $8.705>2.372$, this means that simultaneously the independent variables (communication, problem solving, initiative, planning and organization, self-awareness and technology) have a significant influence on the dependent variable (Entrepreneurship Orientation). In other words, the six independent variables simultaneously influence the entrepreneurial orientation of beef cattle fattening.

Based on Table 2, it can be seen that the t-table of this study is 2,030; if $t$-count $>\mathrm{t}$ table, it means that the independent variable has a significant effect on the dependent variable [9] The results showed that the t-count of all independent variables (communication, problem solving, initiative, planning and organization, self-awareness and technology) partially had no effect on the entrepreneurial orientation of beef cattle fattening in Tasikmadu District because all tcount $<$ ttable. The majority of respondents in Tasikmadu District only make beef cattle fattening a business or a side job to increase the economic value of their families, because the scale of their beef cattle fattening business is still small, with an average of raising 1-5 cattle. According to respondents, the scale of the business has not been able to support the family's economy, if it is used as a business or main job. This statement is in accordance with [15] that most Indonesian people make beef cattle as a side business to increase family income from their main livelihood as farmers, besides that beef cattle are traditionally kept and used as savings. This causes some of the variables used in this study, do not have a significant effect on the entrepreneurial orientation of the farmer members of the Subur Lestari Farmer's Group.

\subsection{Classic assumption test}

Classical assumption tests in this study include multicollinearity test, heteroscedasticity test and autocorrelation test. The multicollinearity test can be seen from the tolerance value or the Variance Inflation Factor (VIF) value. The tolerance value limit is not less than 0.1 and the VIF value is not more than 10, so it can be concluded that the model used is free of multicollinearity between the independent variables in the regression [14]. The results show the tolerance value of all independent variables has a tolerance value $>0.1$ and the VIF value is less than 10. These results can be concluded that there is no multicollinearity between independent variables in the regression model.

According to [12], to test the autocorrelation can use the Durbin Watson statistical test (dw test) using SPSS. The decision making for the absence of autocorrelation in the Durbin Watson test is $\mathrm{du}<\mathrm{dw}<4$-du, where the value of du is obtained from the Durbin Watson statistical table. The value of $\mathrm{dw}$ will be compared with the table value with a significance value of 5\%. The number of samples is 42 and the number of variables is 6 , the values observed from table $\mathrm{dw}$ are $\mathrm{dl} 1.202$ and $\mathrm{du} 1.845$. The test results obtained Durbin Watson has a value of 2,050. The test results show that $\mathrm{du}<\mathrm{dw}<4$-du, where $1.845<2.050$ $<2.155$. It can be concluded that there is no autocorrelation. 
The heteroscedasticity test in this study uses the Glejser test, which is regressing absolute residuals with each independent variable. The results of the Glejser test on the significance value will be compared with a value of 0.05 , if the significance value is $>0.05$ then heteroscedasticity is free [12]. The significance results of all variables have a value greater than 0.05 . It can be concluded that there is no heteroscedasticity in the regression model.

\section{Conclusion}

Based on the research that has been done, it can be concluded that the entrepreneurial competence variables consisting of communication, problem solving, initiative, planning and organization, self-awareness and technology have a simultaneous effect on entrepreneurial orientation, but individual variables have no effect on entrepreneurial orientation.

The authors would like to acknowledge the research grant from the Kementerian Pendidikan dan Kebudayaan Riset dan Teknologi Indonesia, through research grant Penelitian Terapan UNS, 2021.

\section{References}

1. H. Y. Prawira, Muhtarudin dan R. Sutrisna. Jurnal Ilmiah Peternakan Terpadu. 3, 250255 (2015)

2. S.H. Purnomo, A. I. Sari, S. Emawati and E.T. Rahayu. IOP Conference Series: Earth and Environmental Science, 518, 012054 (2020)

3. H. Afriani, N. Idris dan Fatati. Jurnal Ilmiah Ilmu-Ilmu Peternakan. 17, 77-83 (2014)

4. Mudjiarto. Membangun Kepribadian dan Kewirausahaan (Graha Ilmu, Yogyakarta, 2006)

5. S.H. Purnomo, E. T Rahayu, A. I Sari and S. Emawati. IOP Conference Series: Earth and Environmental Science, 250, 012093 (2019)

6. A.D. Ratnasari. eJournal Administrasi.Bisnis. 5 (2017)

7. Badan Pusat Statistik (BPS) Kabupaten Karanganyar. Statistik Daerah Kabupaten Karanganyar. Badan Pusat Statistik Karanganyar. Kab. Karanganyar (2020)

8. U. Argoyogi, Umiyasih, D. B. Wijono, dan D. Wahyono. Prosiding Seminar Hasil Penelitian T.A 1998/1999. Balai Penelitian Tanaman Pangan Karangploso. Malang (2000)

9. T. D. Santosa. Jurnal Sainstech Politeknik Indonesia. 1, 17-27 (2016)

10. Sugiyono. Statistika Untuk Penelitian (Alfabeta, Bandung, 2012)

11. M. Abdulrahman, A.M. Sambas, dan S. Anting. Dasar-Dasar Metode Statistika Untuk Penelitian (Pusat Setia, Bandung, 2011)

12. I. Ghozali. Aplikasi Analisis Multivariate Dengan Program SPSS Cetakan Ke-4 (Badan Penerbit Universitas Diponegoro, Semarang, 2011)

13. M. S. Sosroadmidjodjo, dan Soeradji. Peternakan Umum (CV Yasaguna, Jakarta, 2000)

14. D. Priyatno. Statistika Terapan (Gadjah Mada University Press, Yogyakarta, 2016)

15. Suryana. Kewirausahaan: Pedoman Praktis, Kiat dan Proses Menuju Sukses (Salemba Empat, Jakarta, 2011) 